\title{
Abbreviations Including Frequently Cited Sources
}

\author{
$\mathrm{AB}$ \\ Anchor Bible \\ $A B D$ \\ Anchor Bible Dictionary. Edited by David Noel Freedman. 6 vols. New York: \\ Doubleday, 1992. \\ AJEC Ancient Judaism and Early Christianity \\ ANESSup Ancient Near Eastern Studies Supplement Series \\ AYBRL Anchor Yale Bible Reference Library \\ BAGD Walter Bauer, William F. Arndt, F. Wilbur Gingrich, and Frederick W. Danker. \\ Greek-English Lexicon of the New Testament and Other Early Christian \\ Literature. 2nd ed. Chicago: University of Chicago Press, 1979. \\ BASOR Bulletin of the American Schools of Oriental Research \\ BBET \\ BDB \\ Beiträge zur biblischen Exegese und Theologie \\ Francis Brown, S. R. Driver, and Charles A. Briggs, The Brown-Driver-Briggs \\ Hebrew and English Lexicon of the Old Testament. Based on the lexicon of \\ William Gesenius. Peabody: Hendrickson, 1994. \\ BETL Bibliotheca Ephemeridum Theologicarum Lovaniensium \\ Bib \\ Biblica \\ Biblnt \\ Biblical Interpretation \\ BJS \\ $B N$ \\ Brown Judaic Studies \\ Biblische Notizen \\ BZAW \\ $C B Q$ \\ CQS \\ Beihefte zur Zeitschrift für die alttestamentliche Wissenschaft \\ Catholic Biblical Quarterly \\ Companion to the Qumran Scrolls \\ CRINT \\ DCLS \\ Compendia Rerum ludaicarum ad Novum Testamentum \\ Deuterocanonical and Cognate Literature Studies \\ DCLY \\ Deuterocanonical and Cognate Literature Yearbook \\ DJD \\ $D S D$ \\ Discoveries in the Judaean Desert \\ Dead Sea Discoveries \\ DSSSE \\ EJL \\ FAT \\ FOTL \\ The Dead Sea Scrolls Study Edition. Edited by Florentino García Martínez and \\ Eibert J. C. Tigchelaar. 2 vols. Leiden: Brill, 1998. \\ GBSOT \\ Early Judaism and its Literature \\ Forschungen zum Alten Testament \\ Forms of the Old Testament Literature \\ HALOT \\ HAT \\ Guides to Biblical Scholarship Old Testament \\ The Hebrew and Aramaic Lexicon of the Old Testament. Ludwig Koehler, Walter \\ Baumgartner, and Johann J. Stamm. Translated and edited under the super- \\ vision of Mervyn E. J. Richardson. 4 vols. Leiden: Brill, 1994-1999. \\ HBM Hebrew Bible Monographs \\ Hen Henoch \\ HKAT Handkommentar zum Alten Testament \\ HS Hebrew Studies \\ HSS Harvard Semitic Studies \\ HTR Harvard Theological Review \\ HUCA Hebrew Union College Annual
}


IBC

ICC

IEJ

JAJ

JAJSup

JANER

$J A O S$

$J B L$

JBS

JECS

JJS

JNES

JNSL

JPS

$J R A$

JRS

JSJ

JSJSup

Interpretation: A Bible Commentary for Teaching and Preaching

International Critical Commentary

Israel Exploration Journal

Journal of Ancient Judaism

Journal of Ancient Judaism Supplements

Journal of Ancient Near Eastern Religions

Journal of the American Oriental Society

Journal of Biblical Literature

Jerusalem Biblical Studies

Journal of Early Christian Studies

Journal of Jewish Studies

Journal of Near Eastern Studies

Journal of Northwest Semitic Languages

Jewish Publication Society

Journal of Roman Archaeology

Journal of Roman Studies

Journal for the Study of Judaism in the Persian, Hellenistic, and Roman Periods

Journal for the Study of Judaism in the Persian, Hellenistic, and Roman Periods

Supplement Series

JSNTSup Journal for the Study of the New Testament Supplement Series

JSOT

JSOTSup

JSP

JSPSup

JSQ

ISS Journal for the Study of the Old Testament

Journal for the Study of the Old Testament Supplement Series

Journal for the Study of the Pseudepigrapha

Journal for the Study of the Pseudepigrapha Supplement Series

Jewish Studies Quarterly

JSSSup

JTS

Journal of Semitic Studies

LCL

Journal of Semitic Studies Supplement Series

$\mathrm{LCL}$

Journal of Theological Studies

LHBOTS

Loeb Classical Library

LNTS

LSJ

Library of Hebrew Bible/Old Testament Studies

The Library of New Testament Studies

LSTS

Henry George Liddell, Robert Scott, and Henry Stuart Jones. A Greek-English Lexicon. 9th ed. with revised supplement. Oxford: Clarendon, 1996.

NETS

Library of Second Temple Studies

A New English Translation of the Septuagint. Edited by Albert Pietersma and

NICNT

Benjamin G. Wright. New York: Oxford University Press, 2007

NTL

New International Commentary on the New Testament

NTS

New Testament Library

NTOA

OBO

OBT

OTS

New Testament Studies

PFES

Novum Testamentum et Orbis Antiquus

Orbis Biblicus et Orientalis

Overtures to Biblical Theology

Oudtestamentische Studiën

PTSDSSP

$R B$

Publications of the Finnish Exegetical Society

$\operatorname{Rev} Q$

The Princeton Theological Seminary Dead Sea Scrolls Project

Revue biblique

Revue de Qumrân 
RevScRel Revue des sciences religieuses

SBL Society of Biblical Literature

SBLDS Society of Biblical Literature Dissertation Series

SBLEJL Society of Biblical Literature Early Judaism and Its Literature Series

SBLStBL Society of Biblical Literature Studies in Biblical Literature

SPB Studia Post-Biblica

STDJ Studies on the Texts of the Desert of Judah

SUNT Studien zur Umwelt des Neuen Testaments

SVTP Studia in Veteris Testamenti Pseudepigraphica

TBT The Bible Today

TDOT Theological Dictionary of the Old Testament. Edited by G. Johannes Botterweck and Helmer Ringgren. Translated by John T. Willis et al. 8 vols. Grand Rapids: Eerdmans, 1974-2006.

ThWQ Theologisches Wörterbuch zu den Qumrantexten. Edited by Heinz-Josef Fabry and Ulrich Dahmen. 3 vols. Stuttgart: Kohlhammer, 2010-2016.

TSAJ Texte und Studien zum Antiken Judentum

TU Texte und Untersuchungen

UTB Uni-Taschenbücher

VT Vetus Testamentum

VTSup Vetus Testamentum Supplement

VWGTh Veröffentlichungen der Wissenschaftlichen Gesellschaft für Theologie

WBC Word Biblical Commentary

WUNT Wissenschaftliche Untersuchungen zum Neuen Testament

ZAH Zeitschrift fur Althebraistik

ZAW Zeitschrift für die alttestamentliche Wissenschaft

ZNW Zeitschrift fur die neutestamentliche Wissenschaft und die Kunde der alteren Kirche 
